\title{
HOUSING INDICATORS FOR ASSESSING QUALITY OF LIFE IN LITHUANIA
}

\author{
Dalia ŠTREIMIKIENĖ \\ Mykolas Romeris University \\ E-mail: daliastreimikiene@mruni.eu \\ doi:10.13165/IE-14-8-1-02
}

\begin{abstract}
The paper deals with quality of life in terms of housing and develops the indicator system for quality of life assessment in the housing sector. The increase of the quality of life is the main aim of sustainable development. The quality of life is being assessed by applying various dimensions, various indicators. The housing dimension is one of the major issues affecting the quality of life. The housing indicators reflecting the quality of life can be assessed by applying quality of housing, quality of housing environment and housing cost burden indicators. The paper presents the concept of assessment of housing dimension in the quality of life measurements and the main indicators relevant to this dimension of quality of life. The dynamics of housing indicators relevant to quality of life were investigated in Lithuania and other EU Member States, the housing indicators were compared for three Baltic States and policy recommendations were developed.
\end{abstract}

JEL classification: I31, I38, O47.

Keywords: quality of life, housing quality, housing environment, housing expenditure burden, assessment.

Reikšminiai žodžiai: gyvenimo kokybẻ, būsto kokybẻ, būsto aplinka, išlaidų būstui našta, vertinimas.

\section{Introduction}

The quality of life can be used as the most general aim of sustainable development, as this aim represents the economic, social and environmental dimensions of sustainable development. In this context, it is important to assess the quality of life by evaluating the economic, social and environmental indicators related to quality of life $[1 ; 2]$.

Indicators are a very useful tool to develop policies and monitor the effectiveness and results achieved by these policies. Indicators are tools that measure, simplify and communicate important issues and trends. They can help people understand the essence of sustainable development issues and the relationships between them. Indicators are useful means of measuring progress, but also valuable tool to raise awareness of the key issues among the public and policy-makers, and to help people understand what they themselves need to do. 
The term quality of life is used to evaluate the general well-being of individuals and societies. As this is the key issue of sustainable development, it is very important to develop the system of measurement of quality of life. The term of quality of life is used in a wide range of contexts, including the fields of international development, healthcare, environment and politics. Quality of life should not be mixed with the concept of standard of living, which is based primarily on income $[3 ; 4]$.

The standard indicators of the quality of life usually include not only wealth and employment, but also the built environment, physical and mental health, education, recreation and leisure time, crime rate and social belonging. Also the quality of life is tightly related with such issues as freedom, human rights, and happiness $[5 ; 6]$. Since the quality of life is a complex phenomenon and many of its determinants are strongly correlated, assessing the quality of life requires a comprehensive framework that includes a large number of components and allows assessing how their interrelations shape people's lives.

The concept of housing conditions is very broad and encompasses both the dwelling's physical attributes and satisfaction with housing. Overall, if housing conditions are good on one hand, high housing costs constitute a major concern for households in many countries on the other [6; 7].

In general, having satisfactory accommodation is one of the most valuable aspects of people's lives and it is a major element of people's material living standards. It is essential to meet the basic needs, such as for shelter from weather conditions, and to offer a sense of personal security, privacy and personal space. Good housing conditions are also essential for people's health and affect childhood development. Housing costs make up a large share of the household budget and constitute the main component of household wealth. There are no core set of housing indicators and there is a need for more comparable data in this field. Everyone has the right to adequate housing, which means more than just four walls and a roof over one's head. Housing is essential to meet the basic needs, such as being sheltered from extreme weather and climate conditions. Housing should offer people a suitable place to sleep and rest, where they are free of risks and hazards. In addition, housing should give a sense of personal security, privacy and persona space. Finally, housing is important to satisfy other essential needs, such as having a family. All of these elements make a "house" a "home" and are intrinsically valuable to people.

The aim of the paper is to define the concept of assessment of housing in terms of quality of life and to define the main indicators for assessment of housing impact on quality of life. The main tasks of the paper are: to develop the system of housing indicators relevant to quality of life, to analyse the trends of housing indicators in Lithuania and to compare them with the same indicators in the old EU Member States and the Baltic States and to develop policy recommendations based on this analysis.

\section{Housing Indicators Related to Quality of Life}

Measuring housing conditions and their effects on people's well-being is a complex task because there are very few comparable indicators [8]. An ideal set of indicators to measure housing conditions should provide information about both the physical 
characteristics of the dwelling (e.g. availability of electricity, water supply, indoor flushing toilets, bathroom requirements, cooking facilities, the quality of materials and construction and whether parts of the dwelling are deteriorated or damaged) and the broader environmental characteristics of the areas where the dwellings are located (e.g. exposure to noise, indoor pollution, etc.). However, housing costs make up a large share of the household budget, and low income population is often constrained by the level of resources left for other essential expenditures, such as food, healthcare and education. High housing costs can thus threaten households' material well-being and economic security. They may also generate forms of housing stress that may seriously hamper relations between household members and impair the development of children. In Table 1 , the housing indicators relevant to quality of life are presented.

Table 1. Housing indicators relevant to quality of life

\begin{tabular}{|l|l|l|l|}
\hline \multicolumn{1}{|c|}{ Dimensions } & \multicolumn{3}{|c|}{ Indicators } \\
\hline Housing quality & Overcrowding rate, \% & $\begin{array}{l}\text { Housing deprivation } \\
\text { rate by number of } \\
\text { items, \% }\end{array}$ & $\begin{array}{l}\text { Share of total population } \\
\text { considering their } \\
\text { dwelling as too dark, \% }\end{array}$ \\
\hline $\begin{array}{l}\text { Housing } \\
\text { environment }\end{array}$ & $\begin{array}{l}\text { Crime, violence or } \\
\text { vandalism in the } \\
\text { area,\% }\end{array}$ & $\begin{array}{l}\text { Noise from } \\
\text { neighbours or from } \\
\text { the street, \% }\end{array}$ & $\begin{array}{l}\text { Pollution, grime or } \\
\text { other environmental } \\
\text { problems, \% }\end{array}$ \\
\hline $\begin{array}{l}\text { Housing } \\
\text { expenditure burden }\end{array}$ & $\begin{array}{l}\text { Housing cost } \\
\text { overburden rate, \% }\end{array}$ & $\begin{array}{l}\text { Inability to keep home } \\
\text { adequately warm, \% }\end{array}$ & $\begin{array}{l}\text { Inability to pay utility } \\
\text { bills, \% }\end{array}$ \\
\hline
\end{tabular}

As one can see from the information provided in Table 1, the main indicators of housing consist of three main groups of indicators addressing the most important issues of housing having impact on quality of life.

\section{Housing quality}

One major element of the quality of housing conditions is the availability of sufficient space in the dwelling. The main indicator that has been developed to describe space problems is the overcrowding rate, which assesses the proportion of people living in an overcrowded dwelling, as defined by the number of rooms available to the household, the household's size, as well as its members' age and family situation. However, this indicator does not take into account the possible trade-off between the size of the dwelling, the proximity of public services, such as schools and hospitals, which also matters to people's well-being. Sometimes households choose to live in smaller houses or apartments located in better serviced areas, rather than in larger homes located in poorer neighbourhoods. However, the indicator developed by EUROSTAT overcomes major problems related with such indicators, such as rooms or space per household. Therefore, this indicator provides information on housing overcrowding, which has long been identified as a major housing problem (Myers et al., 1996). Having sufficient space is essential to meet people's basic need for privacy and for making home a pleasant place to be. Too many tenants in a dwelling may 
also have a negative impact on children's health or school performance. Table 2 presents the dynamics of housing overcrowding rate in the EU Member States.

Table 2. Housing overcrowding rate, $\%$

\begin{tabular}{|l|c|c|c|c|c|c|c|c|}
\hline & $\mathbf{2 0 0 5}$ & $\mathbf{2 0 0 6}$ & $\mathbf{2 0 0 7}$ & $\mathbf{2 0 0 8}$ & $\mathbf{2 0 0 9}$ & $\mathbf{2 0 1 0}$ & $\mathbf{2 0 1 1}$ & $\mathbf{2 0 1 2}$ \\
\hline $\begin{array}{l}\text { European Union } \\
\text { (27 countries) }\end{array}$ & 19.5 & 19.1 & 18.8 & 18.4 & 17.9 & 17.7 & 17.0 & 16.9 \\
\hline $\begin{array}{l}\text { European Union } \\
\text { (15 countries) }\end{array}$ & 10.8 & 10.6 & 10.6 & 10.5 & 10.3 & 10.4 & 10.3 & 10.4 \\
\hline Belgium & 4.0 & 3.6 & 3.8 & 4.1 & 3.9 & 4.2 & 2.2 & 1.6 \\
\hline Bulgaria & $:$ & 48.2 & 51.1 & 48.1 & 47.0 & 47.4 & 47.4 & 44.5 \\
\hline Czech Republic & 33.6 & 33.8 & 32.7 & 29.8 & 26.6 & 22.5 & 21.1 & 21.1 \\
\hline Denmark & 7.4 & 7.1 & 7.4 & 7.3 & 7.8 & 7.3 & 7.7 & 7.4 \\
\hline Estonia & 46.1 & 45.9 & 43.5 & 41.7 & 41.2 & 39.7 & 14.4 & 14.0 \\
\hline Ireland & 5.4 & 6.2 & 4.9 & 4.7 & 3.7 & 3.4 & 2.6 & \\
\hline Greece & 29.2 & 29.3 & 29.2 & 26.7 & 25.0 & 25.5 & 25.9 & 26.5 \\
\hline Spain & 8.4 & 6.5 & 5.8 & 5.6 & 5.2 & 5.0 & 6.6 & 5.6 \\
\hline France & 9.4 & 8.1 & 10.1 & 9.7 & 9.6 & 9.2 & 8.0 & 8.1 \\
\hline Italy & 24.2 & 24.3 & 24.4 & 24.2 & 23.3 & 23.9 & 25.0 & 26.2 \\
\hline Cyprus & 2.2 & 1.9 & 1.6 & 3.3 & 2.6 & 3.5 & 2.9 & 2.8 \\
\hline Latvia & 59.8 & 60.2 & 61.1 & 58.1 & 57.7 & 57.1 & 44.3 & 37.3 \\
\hline Lithuania & 52.8 & 53.5 & 52.5 & 49.9 & 49.0 & 46.4 & 19.5 & 19.0 \\
\hline Luxembourg & 9.6 & 7.7 & 7.7 & 8.0 & 6.4 & 7.8 & 6.8 & 7.0 \\
\hline Hungary & 49.9 & 51.2 & 47.4 & 48.3 & 46.8 & 47.2 & 47.1 & 47.2 \\
\hline Malta & 3.5 & 2.8 & 4.0 & 3.8 & 4.0 & 4.1 & 4.2 & 4.3 \\
\hline Netherlands & 1.9 & 1.8 & 1.9 & 1.7 & 1.7 & 2.0 & 1.7 & 2.5 \\
\hline Austria & 13.5 & 15.6 & 15.2 & 15.0 & 13.2 & 12.1 & 11.6 & \\
\hline Poland & 54.1 & 54.1 & 52.3 & 50.8 & 49.1 & 47.5 & 47.2 & 46.3 \\
\hline Portugal & 16.5 & 15.8 & 16.1 & 15.7 & 14.1 & 14.6 & 11.0 & 10.1 \\
\hline
\end{tabular}

As one can see from Table 2, the highest overcrowding rates in 2012 were observed in Romania (54.2\%), Bulgaria (47.4\%), Poland (47.2\%) and Hungary (47.1\%), while the lowest were seen in the Netherlands (1.7\%) and Belgium (2.2\%). The EU-27 average rate of overcrowding was $16.9 \%$ and in Lithuania it was significantly higher - $19 \%$. In the $\mathrm{EU}$ as a whole and in more than half of the EU countries the overcrowding rate is higher, if single person households are excluded from the computation of the indicator. Overall, in the EU-27, the overcrowding rate is higher for those who are at risk-of-poverty (i.e. people living in households, where equivalised disposable income per person was below $60 \%$ of the national median) compared to the total population.

Housing quality can also be assessed by looking at other housing deficiencies, such as lack of certain basic sanitary facilities in the dwelling (such as a bath or shower or indoor flushing toilet) and problems in the general condition of the dwelling (leaking roof or dwelling being too dark). 
Housing deprivation rate is the indicator providing assessment of selected housing deficiencies. The focus is on the lack of facilities for personal hygiene, as this is clearly detrimental to individuals' health and dignity. This indicator sheds light on the quality of the accommodation and provides a proxy measure of the notion of "decent housing". Two basic facilities are considered here: indoor flushing toilets (measured as the percentage of people not having an indoor flushing toilet for the sole use of the household) and bathrooms (measured as the percentage of people having neither a bath nor a shower). The notion of "decent housing" includes other basic aspects of housing conditions, such as the quality of the roofs, floors, doors and window frames, which may also have adverse effects on people's health conditions and comfort. In Table 3, the dynamics of severe house deprivation in the EU Member States is presented.

Table 3. Severe housing deprivation rate, $\%$

\begin{tabular}{|l|c|c|c|c|c|c|c|c|}
\hline & $\mathbf{2 0 0 5}$ & $\mathbf{2 0 0 6}$ & $\mathbf{2 0 0 7}$ & $\mathbf{2 0 0 8}$ & $\mathbf{2 0 0 9}$ & $\mathbf{2 0 1 0}$ & $\mathbf{2 0 1 1}$ & $\mathbf{2 0 1 2}$ \\
\hline $\begin{array}{l}\text { European Union } \\
\text { (27 countries) }\end{array}$ & 8.2 & 7.8 & 7.2 & 6.6 & 6.0 & 5.7 & 5.5 & 5.1 \\
\hline $\begin{array}{l}\text { European Union } \\
\text { (15 countries) }\end{array}$ & 3.5 & 3.4 & 3.3 & 3.3 & 3.3 & 3.2 & 3.4 & 3.1 \\
\hline Belgium & 1.7 & 1.1 & 1.2 & 1.1 & 1.3 & 1.9 & 1.0 & 0.6 \\
\hline Bulgaria & & 22.8 & 18.2 & 23.5 & 18.8 & 14.7 & 14.3 & 12.9 \\
\hline Czech Republic & 9.8 & 10.7 & 8.1 & 6.5 & 6.2 & 4.5 & 4.8 & 3.9 \\
\hline Denmark & 1.2 & 1.3 & 1.7 & 1.1 & 1.3 & 1.3 & 2.6 & 2.2 \\
\hline Estonia & 17.5 & 15.3 & 14.6 & 10.4 & 12.2 & 11.4 & 4.9 & 4.7 \\
\hline Ireland & 1.6 & 2.4 & 1.7 & 0.8 & 1.0 & 0.5 & 0.7 & \\
\hline Greece & 9.1 & 9.1 & 8.5 & 8.1 & 7.6 & 7.6 & 7.2 & 7.0 \\
\hline Spain & 2.9 & 2.6 & 2.6 & 1.6 & 1.8 & 1.8 & 2.1 & 1.3 \\
\hline France & 3.0 & 2.7 & 3.3 & 3.4 & 3.0 & 3.0 & 2.5 & 2.6 \\
\hline Italy & 8.0 & 7.7 & 7.2 & 7.4 & 7.3 & 6.7 & 8.8 & 8.4 \\
\hline Latvia & 31.4 & 27.6 & 25.3 & 22.6 & 22.7 & 22.6 & 17.9 & 16.5 \\
\hline Lithuania & 28.3 & 26.0 & 21.9 & 19.8 & 16.8 & 13.6 & 7.6 & 7.1 \\
\hline Luxembourg & 2.2 & 1.8 & 2.1 & 2.4 & 1.7 & 2.3 & 1.9 & 2.4 \\
\hline Hungary & 22.6 & 19.0 & 14.4 & 20.6 & 11.6 & 17.7 & 16.0 & 17.2 \\
\hline Malta & 0.9 & 0.7 & 0.7 & 0.9 & 1.3 & 1.3 & 1.5 & 1.4 \\
\hline Netherlands & 0.5 & 0.5 & 0.8 & 0.6 & 0.5 & 0.5 & 0.5 & 0.9 \\
\hline Austria & 3.3 & 3.9 & 3.8 & 4.8 & 4.2 & 4.1 & 3.5 & \\
\hline Poland & 29.7 & 28.6 & 25.9 & 18.1 & 15.2 & 13.3 & 11.4 & 10.5 \\
\hline Portugal & 7.7 & 7.5 & 7.6 & 6.9 & 4.7 & 5.6 & 4.0 & 4.3 \\
\hline Romania & & & 31.8 & 30.2 & 28.6 & 26.9 & 25.9 & 22.8 \\
\hline
\end{tabular}

As one can see from Table 3 in 2012, the housing deprivation rate in the EU was $5.5 \%$ and it was more than double for the population at risk of poverty. In Lithuania, housing deprivation rate was $7 \%$ and slightly exceeded the EU-27 average. The highest rates for the total population were exhibited by Romania (25.9\%) and Latvia (17.9 \%). The housing 
deprivation rate was below $1 \%$ of the total population in Finland and the Netherlands. In Romania, $53.0 \%$ of the population that was at-risk-of poverty faced housing deprivation.

In 2012, in all the EU $16.3 \%$ were found to suffer from one of the dwelling problems, $4.1 \%$ suffered from two, $0.9 \%$ suffered from three and $0.3 \%$ suffered from all of the four dwelling problems (i.e. leaking roof/damp walls/floors/foundation or rot in window frames and accommodation being too dark and no bath/shower and no indoor flushing toilet for sole use of the household). At the EU-level, the main housing problem was found to be a 'leaking roof' (i.e. leaking roof or damp walls, floors or foundation, or rot in window frames or floor') (15.5\%), followed by 'darkness of the dwelling' (6.8\%) while less than $3.5 \%$ of the EU population lacked basic sanitary facilities (i.e. lack of bath/shower or indoor flushing toilet). Exceptions to this EU trend are Bulgaria, Estonia, Latvia, Lithuania and Romania, where sanitary problems were found to be equally or more frequent than the other two housing problems mentioned above.

The other indicator of housing quality - the share of population considering their dwelling as too dark is calculated by EUROSTAT and provides important information on living conditions. In Table 4, the dynamics of the share of total population considering their dwelling as too dark is presented in the EU Member States.

Table 4. The share of total population considering their dwelling as too dark, $\%$

\begin{tabular}{|l|c|c|c|c|c|c|c|c|}
\hline & $\mathbf{2 0 0 5}$ & $\mathbf{2 0 0 6}$ & $\mathbf{2 0 0 7}$ & $\mathbf{2 0 0 8}$ & $\mathbf{2 0 0 9}$ & $\mathbf{2 0 1 0}$ & $\mathbf{2 0 1 1}$ & $\mathbf{2 0 1 2}$ \\
\hline $\begin{array}{l}\text { European Union } \\
(27 \text { countries })\end{array}$ & 8.1 & 8.0 & 8.2 & 7.2 & 7.3 & 6.8 & 6.8 & 6.1 \\
\hline $\begin{array}{l}\text { European Union } \\
(15 \text { countries })\end{array}$ & 7.9 & 8.0 & 8.1 & 7.0 & 7.2 & 6.7 & 6.7 & 6.0 \\
\hline Belgium & 9.8 & 10.0 & 8.6 & 7.9 & 9.6 & 8.8 & 7.8 & 3.1 \\
\hline Bulgaria & 9.8 & 9.8 & 9.8 & 8.0 & 6.8 & 7.7 & 7.0 & 6.1 \\
\hline Czech Republic & 6.2 & 4.7 & 4.4 & 4.1 & 4.3 & 3.7 & 3.6 & 3.1 \\
\hline Denmark & 4.0 & 3.9 & 4.6 & 4.3 & 4.5 & 4.2 & 5.1 & 3.8 \\
\hline Estonia & 7.4 & 6.0 & 7.2 & 5.4 & 4.7 & 4.1 & 4.7 & 5.6 \\
\hline Ireland & 5.7 & 6.3 & 9.2 & 5.4 & 5.6 & 4.3 & 4.7 & \\
\hline Greece & 6.1 & 7.7 & 7.5 & 6.8 & 6.7 & 7.1 & 6.7 & 6.9 \\
\hline Spain & 10.8 & 11.8 & 10.8 & 5.9 & 7.0 & 5.6 & 4.3 & 4.4 \\
\hline France & 7.8 & 7.9 & 8.4 & 8.2 & 7.5 & 8.3 & 7.8 & 7.7 \\
\hline Italy & 8.5 & 8.2 & 8.3 & 7.9 & 7.9 & 6.6 & 8.8 & 7.4 \\
\hline Cyprus & 5.6 & 5.6 & 6.4 & 5.2 & 6.7 & 5.9 & 5.4 & 4.5 \\
\hline Latvia & 15.4 & 13.6 & 12.0 & 11.6 & 10.9 & 10.9 & 9.8 & 10.0 \\
\hline Lithuania & 12.3 & 11.2 & 10.6 & 10.2 & 8.8 & 8.2 & 7.8 & 7.0 \\
\hline Luxembourg & 6.0 & 5.3 & 4.9 & 5.6 & 7.0 & 4.4 & 4.1 & 6.6 \\
\hline Hungary & 10.0 & 7.4 & 10.5 & 10.1 & 8.4 & 8.7 & 8.6 & 8.2 \\
\hline Netherlands & 5.2 & 4.8 & 5.2 & 3.9 & 3.7 & 3.8 & 3.8 & 3.9 \\
\hline Austria & 7.1 & 6.9 & 5.7 & 6.9 & 6.5 & 6.9 & 5.9 & \\
\hline Poland & 10.7 & 9.9 & 9.1 & 8.4 & 8.3 & 7.7 & 7.0 & 6.5 \\
\hline Portugal & 17.3 & 18.8 & 17.2 & 11.5 & 8.6 & 7.3 & 7.1 & 9.8 \\
\hline Romania & & & 7.6 & 8.2 & 8.7 & 7.6 & 7.7 & 6.4 \\
\hline
\end{tabular}


As one can see from the information provided in Table 3, the highest share of population considering their dwelling as too dark is in Latvia, followed by Portugal and France.

\section{Housing environment}

Housing quality depends not only on the quality of the dwelling itself, but also on the wider residential area. In this case, the indicators rely on the subjective opinion of the respondents, but have the advantage of drawing a more complete picture of housing. In $2011,19.9 \%$ of the EU-27 population lived in a dwelling where noise from neighbours or from the street was perceived as a problem. Over $30 \%$ of people in Malta were concerned with noise, followed by Romania (28.0 \%), Cyprus (27.2 \%), Germany (25.8 \%) and Greece $(25.1 \%)$. At the other extreme, the rates were lowest in Hungary (9.8 \%), Bulgaria (12.2\%) and Estonia (12.7\%).

The indicator measuring the share of population exposed to the crime, violence or vandalism in the area is very important indicator providing the quality of living conditions. Living in unsecure area reduces the housing comfort and the price of living area tremendously therefore this is important indicator of quality of life related to housing environment. In Table 5 the dynamics of the share of population exposed to crime, violence or vandalism in the area in EU member states is presented.

Table 5. The share of population exposed to crime, violence or vandalism in the area, $\%$

\begin{tabular}{|l|c|c|c|c|c|c|c|c|}
\hline & $\mathbf{2 0 0 5}$ & $\mathbf{2 0 0 6}$ & $\mathbf{2 0 0 7}$ & $\mathbf{2 0 0 8}$ & $\mathbf{2 0 0 9}$ & $\mathbf{2 0 1 0}$ & $\mathbf{2 0 1 1}$ & $\mathbf{2 0 1 2}$ \\
\hline $\begin{array}{l}\text { European Union } \\
\text { (27 countries) }\end{array}$ & $\mathbf{1 6 . 0}$ & $\mathbf{1 5 . 9}$ & $\mathbf{1 5 . 9}$ & $\mathbf{1 4 . 7}$ & $\mathbf{1 6 . 0}$ & 14.4 & 14.2 & 13.7 \\
\hline $\begin{array}{l}\text { European Union } \\
(15 \text { countries) }\end{array}$ & 16.6 & 16.8 & 16.7 & 15.5 & 16.7 & 15.0 & 14.7 & 14.4 \\
\hline Belgium & 17.5 & 18.0 & 17.3 & 15.8 & 16.9 & 17.5 & 15.6 & 14.7 \\
\hline Bulgaria & 24.5 & 24.5 & 27.6 & 24.7 & 28.6 & 27.7 & 27.2 & 26.9 \\
\hline Czech Republic & 16.5 & 14.3 & 13.1 & 13.9 & 17.9 & 15.4 & 15.0 & 13.2 \\
\hline Denmark & 14.0 & 13.6 & 14.0 & 16.2 & 16.5 & 14.2 & 15.3 & 10.3 \\
\hline Estonia & 23.2 & 20.1 & 21.4 & 17.2 & 19.3 & 18.0 & 14.5 & 15.7 \\
\hline Ireland & 14.5 & 16.5 & 15.3 & 12.2 & 14.5 & 10.2 & 10.4 & \\
\hline Greece & 8.2 & 8.5 & 10.4 & 12.0 & 16.3 & 19.1 & 20.1 & 20.1 \\
\hline Spain & 18.9 & 19.3 & 17.5 & 14.7 & 16.4 & 13.0 & 10.8 & 10.1 \\
\hline France & 17.5 & 16.1 & 16.3 & 14.8 & 15.3 & 15.6 & 14.8 & 14.7 \\
\hline Italy & 14.1 & 14.8 & 16.1 & 14.1 & 16.0 & 12.4 & 14.5 & 14.7 \\
\hline Cyprus & 8.9 & 12.9 & 13.6 & 10.1 & 8.3 & 12.7 & 15.0 & 15.5 \\
\hline Latvia & 22.4 & 26.8 & 29.5 & 28.7 & 25.4 & 23.8 & 19.1 & 17.2 \\
\hline Lithuania & 9.0 & 7.8 & 7.1 & 4.9 & 6.6 & 5.2 & 4.8 & 5.0 \\
\hline Luxembourg & 15.4 & 11.1 & 9.7 & 10.6 & 10.6 & 10.2 & 10.7 & 14.4 \\
\hline Hungary & 12.4 & 10.0 & 12.9 & 13.1 & 11.6 & 11.7 & 11.0 & 10.3 \\
\hline Malta & 12.9 & 12.4 & 10.2 & 9.7 & 10.6 & 10.5 & 12.5 & 12.2 \\
\hline
\end{tabular}




\begin{tabular}{|l|c|c|c|c|c|c|c|c|}
\hline Netherlands & 19.0 & 16.7 & 17.7 & 14.8 & 21.7 & 16.8 & 18.6 & 18.3 \\
\hline Austria & 12.7 & 12.1 & 11.4 & 11.1 & 15.1 & 13.4 & 12.1 & $:$ \\
\hline Poland & 10.4 & 9.0 & 8.0 & 7.3 & 6.7 & 6.5 & 6.3 & 6.3 \\
\hline Portugal & 13.8 & 11.9 & 12.6 & 11.7 & 14.0 & 11.3 & 10.1 & 10.9 \\
\hline
\end{tabular}

As one can see from the information provided in Table 5, in 2012 the highest share of population exposed to crime, violence or vandalism in the area was in Bulgaria, Greece and the Netherlands. The smallest share of population exposed to these problems was in Lithuania and Poland. At the EU-27 level, the greatest difference of 2.8 percentage points between the total population and the population at-risk-of-poverty concerned both noise and crime, violence and vandalism, while the lowest difference (of 1.2 percentage points) concerned pollution.

The indicator measuring the share of total population exposed to the noise from neighbours or from the street represents an important issue of quality of housing environment, as living in a noisy area has negative impact on comfort and human health. Noise pollution is one of the most difficult problems in urban areas and multi-flat houses. In Table 6, the dynamics of the share of population exposed to noise from neighbours or from the street in the EU Member States is presented.

Table 6. The share of population exposed to noise from neighbours or from the street, $\%$

\begin{tabular}{|l|c|c|c|c|c|c|c|c|}
\hline & $\mathbf{2 0 0 5}$ & $\mathbf{2 0 0 6}$ & $\mathbf{2 0 0 7}$ & $\mathbf{2 0 0 8}$ & $\mathbf{2 0 0 9}$ & $\mathbf{2 0 1 0}$ & $\mathbf{2 0 1 1}$ & $\mathbf{2 0 1 2}$ \\
\hline $\begin{array}{l}\text { European Union } \\
(27 \text { countries })\end{array}$ & 24.0 & 23.8 & 23.1 & 21.9 & 22.2 & 20.6 & 19.8 & 18.9 \\
\hline $\begin{array}{l}\text { European Union } \\
(15 \text { countries })\end{array}$ & 24.0 & 24.1 & 23.4 & 22.2 & 22.4 & 21.0 & 20.5 & 19.5 \\
\hline Belgium & 23.3 & 22.5 & 22.9 & 21.0 & 19.4 & 18.9 & 19.7 & 11.5 \\
\hline Bulgaria & 17.7 & 17.7 & 15.9 & 16.9 & 16.2 & 12.9 & 12.2 & 12.0 \\
\hline Czech Republic & 21.3 & 18.8 & 18.4 & 17.6 & 18.7 & 16.5 & 15.3 & 14.3 \\
\hline Denmark & 17.8 & 18.4 & 19.9 & 18.4 & 19.4 & 18.7 & 18.8 & 17.5 \\
\hline Estonia & 21.4 & 22.4 & 22.8 & 18.0 & 12.7 & 11.0 & 12.7 & 12.8 \\
\hline Ireland & 11.6 & 14.5 & 13.0 & 12.0 & 10.4 & 9.5 & 9.3 & \\
\hline Greece & 20.2 & 19.9 & 21.7 & 22.3 & 23.5 & 23.2 & 25.1 & 25.1 \\
\hline Spain & 28.6 & 26.5 & 25.6 & 22.0 & 22.4 & 18.4 & 15.6 & 15.0 \\
\hline France & 20.1 & 19.5 & 19.0 & 17.8 & 18.9 & 18.5 & 18.5 & 17.0 \\
\hline Italy & 25.4 & 25.1 & 25.3 & 24.3 & 26.0 & 22.2 & 20.8 & 17.7 \\
\hline Cyprus & 32.3 & 36.0 & 36.8 & 29.7 & 30.6 & 29.0 & 27.5 & 25.7 \\
\hline Latvia & 21.5 & 20.9 & 21.9 & 20.5 & 19.1 & 17.3 & 16.0 & 15.4 \\
\hline Lithuania & 19.8 & 20.0 & 18.5 & 16.6 & 16.1 & 14.1 & 13.9 & 13.3 \\
\hline Luxembourg & 25.2 & 22.5 & 22.0 & 20.0 & 21.2 & 16.7 & 14.6 & 17.0 \\
\hline Hungary & 21.5 & 17.1 & 14.8 & 12.2 & 13.2 & 11.4 & 9.8 & 10.2 \\
\hline Malta & 23.8 & 25.9 & 23.8 & 24.6 & 27.8 & 27.1 & 30.4 & 29.8 \\
\hline Netherlands & 33.1 & 31.3 & 32.1 & 29.3 & 25.3 & 23.6 & 23.6 & 24.2 \\
\hline
\end{tabular}




\begin{tabular}{|l|l|l|l|l|l|l|l|l|}
\hline Austria & 20.5 & 18.7 & 19.8 & 21.7 & 20.9 & 21.2 & 19.1 & \\
\hline Poland & 21.4 & 19.7 & 19.3 & 18.7 & 17.7 & 16.2 & 14.5 & 14.2 \\
\hline Portugal & 25.9 & 25.3 & 27.5 & 24.2 & 23.9 & 22.9 & 23.1 & 23.8 \\
\hline Romania & & & 34.5 & 31.3 & 34.9 & 31.5 & 28.0 & 27.1 \\
\hline
\end{tabular}

As one can see from Table 6, the highest share of population exposed to noise from the street is in Portugal, followed by Greece. In Lithuania, this indicator is quite low (15.4\%), compared to the EU-27 average (18.9\%) in 2012.

Pollution, grime or exposure to other environmental problems represents the quality of housing environment and has a direct impact on human health and living conditions. Large and comfortable houses in polluted environment do not provide for satisfactory living conditions and this is also being reflected by prices of the living area in polluted regions and locations. Table 7 presents the dynamics of the share of population exposed to pollution, grime or other environmental problems in the EU Member States.

Table 7. The share of population exposed to pollution, grime or other environmental problems, \%

\begin{tabular}{|l|c|c|c|c|c|c|c|c|}
\hline & $\mathbf{2 0 0 5}$ & $\mathbf{2 0 0 6}$ & $\mathbf{2 0 0 7}$ & $\mathbf{2 0 0 8}$ & $\mathbf{2 0 0 9}$ & $\mathbf{2 0 1 0}$ & $\mathbf{2 0 1 1}$ & $\mathbf{2 0 1 2}$ \\
\hline $\begin{array}{l}\text { European Union } \\
\text { (27 countries) }\end{array}$ & $\mathbf{1 7 . 6}$ & $\mathbf{1 7 . 5}$ & $\mathbf{1 7 . 1}$ & $\mathbf{1 6 . 2}$ & $\mathbf{1 6 . 5}$ & 14.8 & 15.2 & 14.1 \\
\hline $\begin{array}{l}\text { European Union } \\
\text { (15 countries) }\end{array}$ & $\mathbf{1 7 . 6}$ & $\mathbf{1 7 . 6}$ & $\mathbf{1 7 . 2}$ & $\mathbf{1 6 . 4}$ & 16.3 & 14.8 & 15.2 & 14.2 \\
\hline Belgium & 16.8 & 15.8 & 17.3 & 16.1 & 14.6 & 13.6 & 16.5 & 15.3 \\
\hline Bulgaria & 22.7 & 22.7 & 24.7 & 20.2 & 20.6 & 16.2 & 15.9 & 15.0 \\
\hline Czech Republic & 19.8 & 19.4 & 17.0 & 17.0 & 20.1 & 18.5 & 17.7 & 15.5 \\
\hline Denmark & 6.7 & 7.9 & 8.0 & 7.7 & 7.7 & 8.1 & 8.8 & 5.7 \\
\hline Estonia & 20.6 & 21.3 & 26.4 & 22.3 & 12.3 & 11.3 & 12.4 & 11.9 \\
\hline Ireland & 7.6 & 8.8 & 9.3 & 7.7 & 5.5 & 5.2 & 4.0 & \\
\hline Greece & 18.1 & 17.0 & 18.7 & 20.3 & 22.9 & 25.0 & 25.3 & 25.9 \\
\hline Spain & 16.8 & 16.5 & 15.8 & 13.0 & 13.6 & 10.7 & 8.2 & 8.0 \\
\hline France & 17.1 & 15.4 & 16.4 & 14.3 & 12.9 & 12.9 & 11.7 & 11.3 \\
\hline Italy & 22.1 & 21.5 & 21.1 & 19.8 & 20.7 & 16.8 & 19.4 & 17.1 \\
\hline Cyprus & 20.3 & 24.4 & 25.8 & 20.0 & 21.1 & 19.3 & 19.2 & 15.5 \\
\hline Latvia & 28.0 & 33.1 & 36.8 & 35.2 & 30.2 & 28.5 & 24.0 & 22.2 \\
\hline Lithuania & 14.0 & 13.8 & 15.4 & 12.7 & 13.8 & 12.1 & 14.2 & 14.6 \\
\hline Luxembourg & 18.6 & 18.0 & 16.2 & 16.3 & 16.8 & 12.0 & 11.2 & 14.0 \\
\hline Hungary & 17.2 & 12.9 & 13.4 & 11.0 & 11.2 & 11.1 & 12.2 & 11.8 \\
\hline Malta & 33.9 & 38.6 & 35.2 & 36.2 & 38.4 & 41.1 & 41.4 & 40.3 \\
\hline Netherlands & 14.9 & 14.3 & 13.8 & 13.0 & 14.8 & 13.7 & 14.3 & 14.0 \\
\hline Austria & 9.1 & 7.5 & 8.0 & 8.4 & 10.0 & 9.3 & 10.4 & $:$ \\
\hline Poland & 13.8 & 13.0 & 12.9 & 11.5 & 10.9 & 9.3 & 11.2 & 11.0 \\
\hline Portugal & 20.7 & 20.2 & 22.1 & 16.8 & 18.7 & 16.3 & 15.2 & 14.9 \\
\hline Romania & $:$ & $:$ & 18.4 & 17.2 & 24.8 & 20.0 & 19.1 & 17.6 \\
\hline
\end{tabular}


As one can see from Table 7, in $201215.3 \%$ of the EU-27 population perceived the area in which they live as being affected by pollution, grime or other environmental problems. At the country level, the figures ranged from less than $10 \%$ in Sweden, Spain, Finland and Denmark to over $40 \%$ in Malta. Rates were small in Croatia (7.3\%) and Norway $(7.5 \%)$.

The proximity of public services, such as schools and hospitals is an important indicator of quality of life related with housing. The share of population satisfied with housing environment is a perceived indicator and also useful for assessment of quality of life related to housing. The satisfaction with housing environment is a subjective indicator capturing the extent to which people's perceived needs for services in the housing area are met in practice, but this indicator is not being assessed and collected neither by EUROSTAT nor by OECD statistical institutions.

\section{Housing expenditure burden}

The housing cost overburden rate is an indicator of housing affordability. It is measured as the percentage of the population living in households where total housing costs (net of housing allowances) represent $40 \%$ or more of their equivalised disposable income. This indicator is thus a measure of the housing costs effectively supported by households. This indicator is limited to European countries and relies on data from the EU-SILC survey. Housing costs, according to the EU-SILC definition, refer to monthly costs and include actual rents paid, the costs of utilities (water, gas, electricity and heating), housing taxes and compulsory insurance, as well mortgage interest payments and regular maintenance and repairs by home owners, while excluding the repayments of principal on mortgages.

This indicator is an imperfect proxy of the pressure of housing costs on the household budget: indeed, some middle- and high-income households can decide to spend a large amount ( $40 \%$ or more) of their disposable equivalised income for housing, without incurring any form of material deprivation. In Table 8, the dynamics of housing cost overburden rate in the EU Member States is presented.

Table 8. Housing cost overburden rate \%

\begin{tabular}{|l|c|c|c|c|c|c|c|c|}
\hline & $\mathbf{2 0 0 5}$ & $\mathbf{2 0 0 6}$ & $\mathbf{2 0 0 7}$ & $\mathbf{2 0 0 8}$ & $\mathbf{2 0 0 9}$ & $\mathbf{2 0 1 0}$ & $\mathbf{2 0 1 1}$ & $\mathbf{2 0 1 2}$ \\
\hline $\begin{array}{l}\text { European Union } \\
(27 \text { countries })\end{array}$ & 11.5 & 11.6 & 10.6 & 10.5 & 10.0 & 10.9 & 11.6 & 11.3 \\
\hline $\begin{array}{l}\text { European Union } \\
(15 \text { countries })\end{array}$ & 10.0 & 11.1 & 9.9 & 10.0 & 10.2 & 11.1 & 12.1 & 11.1 \\
\hline Belgium & 8.6 & 9.8 & 10.1 & 12.5 & 8.7 & 8.9 & 10.6 & $:$ \\
\hline Bulgaria & $:$ & 15.4 & 21.2 & 13.3 & 7.0 & 5.9 & 8.7 & 14.5 \\
\hline Czech Republic & 10.0 & 10.8 & 10.3 & 12.8 & 8.9 & 9.7 & 9.5 & 10.0 \\
\hline Denmark & 13.6 & 16.1 & 13.4 & 17.1 & 24.2 & 21.9 & 19.9 & 17.8 \\
\hline Estonia & 7.8 & 6.8 & 5.2 & 3.6 & 4.4 & 6.0 & 7.4 & 7.9 \\
\hline Ireland & 2.7 & 2.5 & 3.1 & 3.3 & 4.0 & 4.9 & 6.1 & $:$ \\
\hline
\end{tabular}




\begin{tabular}{|l|c|c|c|c|c|c|c|c|}
\hline Greece & 22.7 & 24.6 & 15.8 & 22.2 & 21.8 & 18.1 & 24.2 & 33.1 \\
\hline Spain & 5.3 & 7.4 & 8.3 & 10.1 & 12.8 & 13.2 & 13.8 & 14.3 \\
\hline France & 5.3 & 6.0 & 5.7 & 4.1 & 3.7 & 5.0 & 5.3 & 5.2 \\
\hline Italy & 12.7 & 12.3 & 7.7 & 8.1 & 7.5 & 7.5 & 8.4 & 7.9 \\
\hline Cyprus & 6.6 & 3.0 & 1.7 & 1.8 & 2.4 & 3.1 & 3.1 & 3.3 \\
\hline Latvia & 12.6 & 10.3 & 9.0 & 8.4 & 8.6 & 9.4 & 12.6 & 11.2 \\
\hline Lithuania & 9.0 & 6.9 & 4.8 & 4.8 & 5.5 & 10.6 & 11.1 & 8.9 \\
\hline Luxembourg & 3.8 & 4.8 & 3.9 & 3.7 & 3.7 & 4.7 & 4.2 & 4.9 \\
\hline Hungary & 18.1 & 12.3 & 10.9 & 11.6 & 8.9 & 11.3 & 11.8 & 13.5 \\
\hline Malta & 1.8 & 1.8 & 2.4 & 3.2 & 2.7 & 3.4 & 2.8 & 2.5 \\
\hline Netherlands & 20.2 & 19.7 & 18.3 & 13.7 & 13.1 & 14.0 & 14.5 & 14.4 \\
\hline Austria & 4.4 & 5.0 & 5.4 & 4.7 & 5.1 & 4.6 & 4.8 & $:$ \\
\hline Poland & 16.5 & 12.0 & 10.5 & 9.7 & 8.2 & 9.1 & 10.2 & 10.5 \\
\hline Portugal & 4.3 & 4.5 & 7.4 & 7.6 & 6.1 & 4.2 & 7.2 & 8.3 \\
\hline Romania & $:$ & $:$ & 18.4 & 18.7 & 15.3 & 15.0 & 9.9 & 16.5 \\
\hline
\end{tabular}

As one can see from the information provided in Table 8 concerning housing expenditures in 2012, $11.5 \%$ of the EU-27 population lived in households that spent more than $40 \%$ of their disposable income on housing. In Greece, Denmark, the United Kingdom, Germany and the Netherlands the housing cost overburden rate exceeded $14.0 \%$, while the lowest rates were reported by Cyprus $(2.7 \%)$ and Malta $(2.8 \%)$. At EU-27 level, the percentage of people whose housing costs exceeded $40 \%$ of their equivalised disposable income was around $11.5 \%$ for all age groups (people below the age of 18, people aged between 18 and 64, people over 65). However, this is not the same in all the EU Member States. In ten Member States, the elderly suffer more than the younger age groups regarding housing cost affordability.

An indicator representing the share of households unable to keep their home adequately warm is a very important indicator representing an economic strain linked to dwelling. In particular, this indicator is important in cold climate countries, such as Eastern Europe, including Lithuania. Table 9, shows the dynamics of the share of population in the EU Member States unable to keep their home adequately warm.

Table 9. The share of population unable to keep their home adequately warm, $\%$

\begin{tabular}{|l|c|c|c|c|c|c|c|c|}
\hline & $\mathbf{2 0 0 5}$ & $\mathbf{2 0 0 6}$ & $\mathbf{2 0 0 7}$ & $\mathbf{2 0 0 8}$ & $\mathbf{2 0 0 9}$ & $\mathbf{2 0 1 0}$ & $\mathbf{2 0 1 1}$ & $\mathbf{2 0 1 2}$ \\
\hline $\begin{array}{l}\text { European Union } \\
(27 \text { countries })\end{array}$ & 12.3 & 11.8 & 10.8 & 10.1 & 9.3 & 9.5 & 9.8 & 10.8 \\
\hline $\begin{array}{l}\text { European Union } \\
(15 \text { countries })\end{array}$ & 7.7 & 7.8 & 7.4 & 7.3 & 7.0 & 7.2 & 8.3 & 9.5 \\
\hline Belgium & 14.1 & 14.5 & 14.6 & 6.4 & 5.1 & 5.6 & 7.1 & 6.6 \\
\hline Bulgaria & 69.5 & 69.5 & 67.4 & 66.3 & 64.2 & 66.5 & 46.3 & 46.5 \\
\hline Czech Republic & 9.3 & 8.9 & 6.1 & 6.0 & 5.2 & 5.2 & 6.4 & 6.7 \\
\hline Denmark & 8.9 & 9.4 & 10.3 & 1.7 & 1.5 & 1.9 & 2.6 & 2.6 \\
\hline
\end{tabular}




\begin{tabular}{|l|c|c|c|c|c|c|c|c|}
\hline Estonia & 2.6 & 2.3 & 3.6 & 1.1 & 1.7 & 3.1 & 3.0 & 4.2 \\
\hline Ireland & 4.0 & 3.8 & 3.5 & 3.7 & 4.1 & 6.8 & 6.8 & \\
\hline Greece & 15.7 & 12.0 & 13.8 & 15.4 & 15.7 & 15.4 & 18.6 & 26.1 \\
\hline Spain & 9.4 & 10.1 & 8.0 & 6.0 & 7.2 & 7.5 & 6.5 & 9.1 \\
\hline France & 5.3 & 5.9 & 4.6 & 5.3 & 5.5 & 5.7 & 6.0 & 6.0 \\
\hline Italy & 10.6 & 10.1 & 10.4 & 11.3 & 10.6 & 11.2 & 18.0 & 21.2 \\
\hline Cyprus & 33.7 & 33.8 & 34.6 & 29.2 & 21.7 & 27.3 & 26.6 & 30.7 \\
\hline Latvia & 29.7 & 25.1 & 22.1 & 16.7 & 16.0 & 18.9 & 22.6 & 20.0 \\
\hline Lithuania & 34.8 & 27.6 & 22.4 & 22.1 & 24.1 & 25.1 & 36.2 & 34.1 \\
\hline Luxembourg & 0.9 & 0.6 & 0.5 & 0.9 & 0.3 & 0.5 & 0.9 & 0.6 \\
\hline Hungary & 17.7 & 14.8 & 10.8 & 9.7 & 8.9 & 10.7 & 11.7 & 14.5 \\
\hline Malta & 12.6 & 10.9 & 9.9 & 8.6 & 11.0 & 13.6 & 17.6 & 21.7 \\
\hline Netherlands & 3.1 & 2.2 & 1.6 & 1.8 & 1.3 & 2.3 & 1.6 & 2.2 \\
\hline Austria & 3.1 & 3.8 & 2.6 & 4.0 & 2.9 & 3.8 & 2.6 & \\
\hline Poland & 33.6 & 28.4 & 22.7 & 20.1 & 16.3 & 14.8 & 13.6 & 13.2 \\
\hline Portugal & 40.0 & 39.9 & 41.9 & 34.9 & 28.5 & 30.1 & 26.8 & 27.0 \\
\hline Romania & & & 32.6 & 24.6 & 22.0 & 21.0 & 15.7 & 14.6 \\
\hline
\end{tabular}

As one can see from the information provided in Table 9, the highest share of population unable to keep their home warm in 2012 was in Bulgaria, Lithuania and Portugal. The lowest indicator was in Luxemburg, Denmark, Netherlands and Estonia.

The indicator of inability to pay utility bills represents the economic strain of households and takes into account high prices for electricity, heat and water supply, etc. compared to low income, what is especially relevant to the situation of the new EU Member States. In Table 10, the dynamics of the share of population unable to pay utility bills in the EU Member States is presented.

Table 10. The share of population unable to pay utility bills, $\%$

\begin{tabular}{|l|c|c|c|c|c|c|c|c|}
\hline & $\mathbf{2 0 0 5}$ & $\mathbf{2 0 0 6}$ & $\mathbf{2 0 0 7}$ & $\mathbf{2 0 0 8}$ & $\mathbf{2 0 0 9}$ & $\mathbf{2 0 1 0}$ & $\mathbf{2 0 1 1}$ & $\mathbf{2 0 1 2}$ \\
\hline $\begin{array}{l}\text { European Union } \\
(27 \text { countries })\end{array}$ & 8.3 & 8.0 & 7.3 & 7.9 & 8.9 & 8.9 & 8.9 & 9.7 \\
\hline $\begin{array}{l}\text { European Union } \\
(15 \text { countries })\end{array}$ & 6.2 & 6.4 & 5.7 & 6.4 & 6.8 & 6.7 & 6.8 & 7.6 \\
\hline Belgium & 5.7 & 5.1 & 4.7 & 5.1 & 5.9 & 5.8 & 6.0 & 6.4 \\
\hline Bulgaria & 19.0 & 19.0 & 28.8 & 33.4 & 32.1 & 31.6 & 28.6 & 28.4 \\
\hline Czech Republic & 7.2 & 5.8 & 3.8 & 2.6 & 4.0 & 4.2 & 4.3 & 4.1 \\
\hline Denmark & 2.8 & 2.5 & 1.8 & 2.2 & 2.6 & 3.2 & 3.9 & 3.6 \\
\hline Estonia & 10.3 & 6.3 & 4.7 & 7.4 & 10.0 & 11.0 & 11.8 & 10.9 \\
\hline Ireland & 6.9 & 6.8 & 6.1 & 8.3 & 11.2 & 12.6 & 14.8 & \\
\hline Greece & 26.5 & 25.0 & 15.7 & 15.9 & 18.9 & 18.8 & 23.3 & 31.8 \\
\hline Spain & 4.5 & 4.3 & 4.6 & 4.6 & 6.3 & 7.5 & 5.7 & 7.5 \\
\hline France & 7.2 & 6.6 & 6.4 & 6.1 & 7.5 & 7.1 & 7.1 & 6.7 \\
\hline
\end{tabular}




\begin{tabular}{|l|c|c|c|c|c|c|c|c|}
\hline Italy & 10.5 & 10.9 & 10.4 & 13.6 & 11.0 & 10.5 & 12.1 & 11.7 \\
\hline Cyprus & 9.7 & 9.9 & 10.0 & 7.5 & 13.3 & 16.3 & 16.9 & 18.4 \\
\hline Latvia & 18.5 & 13.3 & 8.8 & 12.0 & 18.2 & 23.2 & 24.1 & 23.0 \\
\hline Lithuania & 20.7 & 13.8 & 8.9 & 5.9 & 8.5 & 11.1 & 11.8 & 12.6 \\
\hline Luxembourg & 3.2 & 1.6 & 2.1 & 1.1 & 2.3 & 2.1 & 2.2 & 2.2 \\
\hline Hungary & 15.9 & 15.1 & 17.6 & 14.2 & 20.7 & 22.1 & 23.0 & 24.4 \\
\hline Malta & 7.8 & 6.4 & 7.0 & 7.3 & 7.4 & 6.4 & 8.2 & 9.3 \\
\hline Netherlands & 3.2 & 2.7 & 2.2 & 2.2 & 2.1 & 2.1 & 2.4 & 2.3 \\
\hline Austria & 1.7 & 1.8 & 1.9 & 3.6 & 4.2 & 4.6 & 4.1 & \\
\hline Poland & 24.2 & 20.4 & 16.7 & 10.0 & 12.5 & 13.9 & 12.9 & 14.1 \\
\hline Portugal & 5.0 & 4.8 & 5.2 & 3.7 & 6.1 & 6.4 & 6.7 & 6.3 \\
\hline Romania & & & 8.3 & 23.8 & 25.2 & 27.0 & 27.2 & 28.6 \\
\hline
\end{tabular}

As one can see from Table 10, inability to pay utility bills in 2012 made $12.6 \%$ in Lithuania. The EU-27 average made only $9.9 \%$. The highest indicators for inability to pay utility bills are in Bulgaria (28.4\%), Romania (23\%) and Latvia (23\%). The lowest indicator is in Luxemburg, Netherlands and Denmark.

\section{Comparison of Lithuanian housing indicators with those of the other Baltic States}

In order to define the trends of housing indicators in Lithuania and to compare them with the same indicators in the old EU Member States and the Baltic States, Table 11 was developed representing the trends of the main housing indicators relevant to the quality of life in Lithuania from 2005 to 2012. Lithuania has joined the EU in 2004 and these trends therefore also represent the impact of joining the EU on quality of life in terms of housing in Lithuania.

Table 11. The dynamics of housing indicators relevant to the quality of life in Lithuania

\begin{tabular}{|l|c|c|c|c|c|c|c|c|}
\hline \multirow{2}{*}{\multicolumn{1}{|c|}{ Indicators }} & \multicolumn{7}{c|}{ Years } \\
\cline { 2 - 10 } & $\mathbf{2 0 0 5}$ & $\mathbf{2 0 0 6}$ & $\mathbf{2 0 0 7}$ & $\mathbf{2 0 0 8}$ & $\mathbf{2 0 0 9}$ & $\mathbf{2 0 1 0}$ & $\mathbf{2 0 1 1}$ & $\mathbf{2 0 1 2}$ \\
\hline Overcrowding rate, \% & 52.8 & 53.5 & 52.5 & 49.9 & 49 & 46.4 & 19.5 & 19 \\
\hline $\begin{array}{l}\text { Housing deprivation rate by } \\
\text { number of item, \% }\end{array}$ & 28.3 & 26 & 21.9 & 19.8 & 16.8 & 13.6 & 7.6 & 7.1 \\
\hline $\begin{array}{l}\text { Share of total population } \\
\text { considering their dwelling } \\
\text { as too dark, \% }\end{array}$ & 12.3 & 11.2 & 10.6 & 10.2 & 8.8 & 8.2 & 7.8 & 7.0 \\
\hline $\begin{array}{l}\text { Crime, violence or vanda- } \\
\text { lism in the area,\% }\end{array}$ & 9.0 & 7.8 & 7.1 & 4.9 & 6.6 & 5.2 & 4.8 & 5.0 \\
\hline $\begin{array}{l}\text { Noise from neighbours or } \\
\text { from the street, \% }\end{array}$ & 19.8 & 20.0 & 18.5 & 16.6 & 16.1 & 14.1 & 13.9 & 13.3 \\
\hline
\end{tabular}




\begin{tabular}{|l|c|c|c|c|c|c|c|c|}
\hline $\begin{array}{l}\text { Pollution, grime or other } \\
\text { environmental problems, \% }\end{array}$ & 14.0 & 13.8 & 15.4 & 12.7 & 13.8 & 12.1 & 14.2 & 14.6 \\
\hline $\begin{array}{l}\text { The housing cost overbur- } \\
\text { den rate, \% }\end{array}$ & 9.0 & 6.9 & 4.8 & 4.8 & 5.5 & 10.6 & 11.1 & 8.9 \\
\hline $\begin{array}{l}\text { Inability to keep home } \\
\text { adequately warm, \% }\end{array}$ & 34.8 & 27.6 & 22.4 & 22.1 & 24.1 & 25.1 & 36.2 & 34.1 \\
\hline $\begin{array}{l}\text { Inability to pay utility } \\
\text { bills, \% }\end{array}$ & 20.7 & 13.8 & 8.9 & 5.9 & 8.5 & 11.1 & 11.8 & 12.6 \\
\hline Total share, \% & 200.7 & 180.6 & 162.8 & 146.9 & 149.2 & 146.6 & 126.9 & 121.6 \\
\hline
\end{tabular}

As one can see from Table 11, the total estimate of housing indicators related to the quality of life in Lithuania was improving from 2005, but during the economic crisis of 2008 some decline can be noticed and the total share of population encountering problems in the housing sector has increased. The most negative impact of economic crisis was felt by housing expenditures burden indicators, such as housing cost overburden rate, inability to keep the home warm and to pay bills. In Lithuania, indicators related with quality of housing and housing environment have positive trends during the entire period under investigation. Comparing Lithuanian housing indicators with the same indicators in the old EU Member States, one can notice that in advanced and developed countries, such as Luxemburg, Austria, Germany, France, Belgium, Netherlands etc. all housing indicators are lower, showing higher quality of housing, better housing environment and lower housing expenditure rates with some exceptions.

In Lithuania, the dynamics of overcrowding rate has more than halved since 2005 and this is a very positive trend, similar to other house quality indicators analysed in Lithuania. The housing deprivation rate by the number of items has reduced in Lithuania 4 times from 2005 to 2012 . The share of total population considering their dwelling as too dark has halved in Lithuania during 13 years and today $7 \%$ percent of population is considering their dwellings as too dark. The EU-27 average makes $6.1 \%$ and is slightly lower. This indicator in Latvia makes $10 \%$ and is the highest among the EU-27 Member States.

Noise from neighbours or from the street was the problem for $18 \%$ of the total population in the EU in 2012. In Lithuania, this indicator makes $13.3 \%$ and is lower than the EU average and is among the lowest between the EU Member States. The highest indicators of noise are in Germany, Malta, Cyprus and Romania, etc.

In Lithuania, the housing cost overburden rate in 2012 made $8.9 \%$ and reached the 2005 level. This indicator for Lithuania is lower than the EU-27 average. Very high housing cost overburden rates are in Greece (33\%). In Romania, Bulgaria, Denmark, Germany, etc. they are twice as low, reaching $16 \%$.

The indicator of inability to keep their home adequately warm in Lithuania amounted to $34.1 \%$ in 2012 and was among the highest ones. This indicator is higher in Bulgaria only and makes $46 \%$. The EU-27 average makes only $10 \%$, indicating that the situation in Lithuania is alarming.

Inability to pay utility bills in 2012 made $12.6 \%$ in Lithuania. The EU-27 average amounted only to $9.9 \%$. The highest indicators for inability to pay utility bills are in Bulgaria, Romania and Latvia. The best indicators are in Denmark, Iceland, Switzerland, 
the Netherlands. Though the share of housing costs makes a large share of households disposable income in the old EU Member States, the population sees no problem in paying such high utility bills because of average high disposable income, compared to the new EU Member States, including Lithuania.

In Figure 1, the quality of life in terms of housing is compared in the three Baltic States.

Figure 1. Housing indicators relevant to the quality of life in the Baltic States

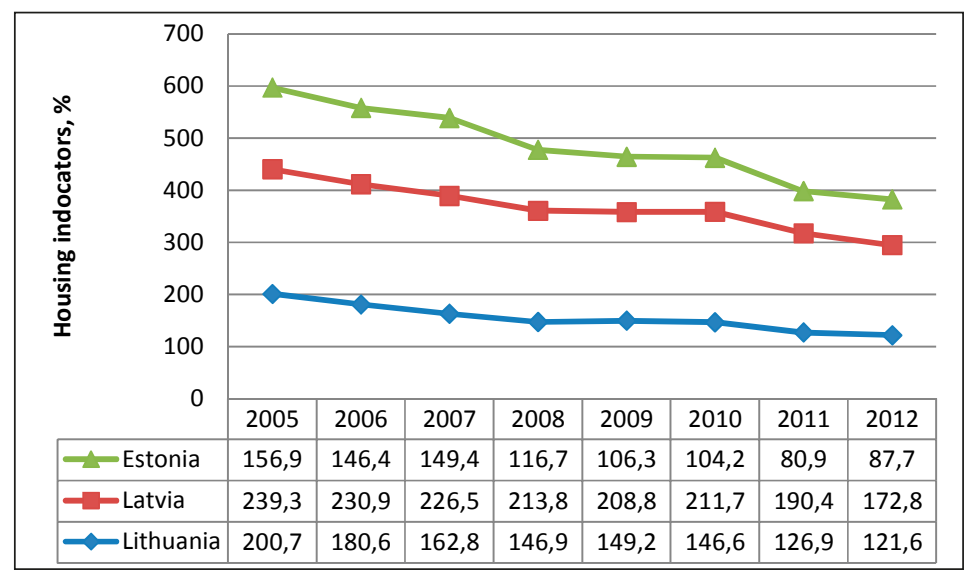

As one can see from Figure 1, the trends of housing indicators relevant to the quality of life were similar in the Baltic States after joining the EU, but Estonia distinguishes with the highest quality of life in terms of housing indicators. The worst situation is in Latvia. In Latvia, the biggest problems are related to overcrowding and housing deprivation rates. Lithuania distinguishes with very high indicators of inability to keep the house warm and Estonia - with a very low indicator of inability to keep the home warm, though Estonia is more North than Lithuania. This shows that certain policies are necessary in Lithuania to address this problem more consistently.

\section{Conclusion}

Measuring housing conditions and their effects on people's well-being is a complex task, as there are very few comparable indicators.

An ideal set of indicators to measure housing conditions should provide information about the physical characteristics of the dwelling and the broader environmental characteristics of the areas where the dwellings are located (e.g. exposure to noise, indoor pollution, etc.) and housing costs that make up a large share of the household budget.

The proposed system of housing indicators relevant to the quality of life includes 3 housing quality, 3 housing environment and 3 housing cost burden indicators. The system 
of indicators represents the share of population experiencing problems related to housing. The higher share represents the lower level of quality of life in terms of housing indicators.

As all housing indicators are measured in percentage terms, it is possible to sum all of the 9 indicators in order to compare the EU Member States in terms of total housing indicators relevant to quality of life.

Comparing the total housing indicators in the three Baltic States, one can note that in Estonia, the quality of life in terms of housing is the highest. In Latvia, the housing indicators are the highest ones, representing the lowest quality of life in terms of housing among the three Baltic States.

Analysis of housing indicator trends in Lithuania showed positive trends in development of all housing quality indicators, but some housing environment quality and housing expenditure burden indicators were stable during the period from 2005 to 2012.

Lithuania distinguishes from the other EU Member States by high housing expenditure indicators. Especially high indicator of inability to keep the home adequately warm shows a very high burden of heating costs for Lithuanian households.

Though the share of housing costs in disposable household income in Lithuania is similar to the EU-27 average, namely $22 \%$, the high indicator of inability to keep the home adequately warm and high indicators of inability to pay utilities shows that Lithuania distinguishes from the other EU Members States with high energy, water etc. supply prices and low disposable income.

Though housing quality indicators in Lithuania have significantly improved during the analysed 13 year period, the other housing indicators (housing environment, housing expenditures burden) were almost stable during the same period.

The policies aiming at housing environment and housing expenditure burden indicators need to be developed, as in these areas Lithuania lags far behind the other EU Member States and the pace of improvement is too slow.

Acknowledgment

This research is funded by the European Social Fund under the Global Grant measure (No. VP1-3.1-ŠMM-07-K-03-032).

\section{References}

1. Albouy, V; Godefroy, P. and Lollivier, S. "Une mesure de la qualité de vie", in INSEE, France, Portrait Social, edition 2010, Paris, 2010, p. 99-114.

2. Boarini, R; Comola, M.; De Keulenauer, F.; Manchin, R. and Smith, C. "The Determinants of Well-being in OECD Countries", OECD Statistics Directorate Working Paper, Paris, 2010

3. Dolan, P.; Peasgood, T. and White, M. "Do we really know what makes us happy? A review of the economic literature on the factors associated with subjective wellbeing", Journal of Economic Psychology, Vol. 29, p. 94-122, 2010.

4. Helliwell, J. F. and Barrington-Leigh, C. P. "Measuring and Understanding Subjective Well-being", NBER Working Paper 15887, National Bureau of Economic Research, 2010 
5. Kahneman, D. and Deaton, A. "High income improves life evaluation but not emotional well-being", Proceedings of the National Academy of Sciences, Vol. 107 (38), p. 16489-16493, 2010.

6. Kahneman, D. and Krueger, A. B. "Developments in the Measurement of Subjective Well-Being” Journal of Economic Perspectives, Vol. 20 (1), p. 19-20, 2006.

7. Kahneman, D.; Diener, E. and Schwarz, N. Well-Being. The Foundations of Hedonic Psychology, New York: Russel Sage Foundation, 1999.

8. Diener, E.; Helliwell, J. F. and Kahneman, D. International Differences in Well-Being, New York: Oxford University Press, 2010.

9. Lucas, R. R. "Long-Term Disability Is Associated With Lasting Changes in Subjective Well-Being: Evidence From Two Nationally Representative Longitudinal Studies”, Journal of Personaility and Social Psychology, vol. 92, (4), p. 717-730, 2007.

10. Bjornskov, C. "How Comparable are the Gallup World Poll Life Satisfaction Data?", Journal of Happiness Studies, vol. 11, p. 41-60, 2010.

11. Sen, A. "Personal utilities and public judgements: or what's wrong with welfare economics”, Economic Journal, No. 89, p. 537-555, 1997.

\section{BŪSTO RODIKLIAI GYVENIMO KOKYBĖS VERTINIMUI LIETUVOJE}

Santrauka. Straipsnyje yra analizuojami būsto rodikliai, lemiantys gyvenimo kokybę. Kadangi gyvenimo kokybès didinimas yra pagrindinis darnaus vystymosi tikslas, būtina ịvertinti gyvenimo kokybę bei palyginti šị rodikli tarp šalių. Būstas yra vien svarbiausių gyvenimo kokybẻs dimensijų ir atspindi tokius svarbius aspektus, kaip būsto kokybẻ, būsto aplinka ir mokesčių už būstą našta. Straipsnyje pristatyta būsto rodiklių, skirtų gyvenimo kokybei vertinti, koncepcija bei sudaryta rodiklių sistema, taip pat apskaičiuotas agreguotas rodiklis. Straipsnyje surinkti Lietuvos būsto rodikliai, atspindintys gyvenimo kokybę, bei atliktas šių rodiklių dinamikos palyginimas tarp Baltijos šalių. Remiantis atlikta analize, parengtos politikos rekomendacijos Lietuvai.

Dalia ŠTREIMIKIENĖ - Habil. Dr. in economics, professor of the Institute of Economics and Business, Faculty of Economics and Finance Management, Mykolas Romeris University.

Scientific research areas: sustainable energy, energy policy, climate change mitigation policies, international trade and economics.

Dalia ŠTREIMIKIENE் - Mykolo Romerio universiteto Ekonomikos ir finansų valdymo fakulteto Ekonomikos ir verslo instituto profesoré, ekonomikos mokslų habilituota daktarè.

Mokslinių tyrimų sritys: darni energetika, energetikos politika, klimato kaitos švelninimo politika, tarptautine prekyba ir ekonomika 